\title{
Prospects and limitations of microbial pesticides for control of bacterial and fungal pomefruit tree diseases
}

\author{
A. Bonaterra $\cdot$ E. Badosa $\cdot$ J. Cabrefiga $\cdot$ \\ J. Francés $\cdot$ E. Montesinos
}

Received: 14 May 2011 / Revised: 20 July 2011 / Accepted: 15 September 2011 / Published online: 2 October 2011

(C) Springer-Verlag 2011

\begin{abstract}
The tree constitutes an ecosystem in which microorganisms play an essential role in its functionality. Interactions that microorganisms establish with plants may be beneficial or detrimental and are of extreme importance in the exploitation of trees in agriculture as crop production systems. Fruit trees, especially pomefruit trees including apple, pear and several ornamentals are of great economic importance but its production is affected by several diseases. Fungal and bacterial fruit tree diseases are mainly controlled with chemical fungicides and bactericides, but health and environmental concerns about the use of chemical pesticides have result in strong regulatory actions and have stimulated the development of beneficial microorganisms as microbial pesticides. Up to now, several microorganisms have been registered in different countries and in the EU as biocontrol agents (BCA) covering mainly fire blight, soil-borne fungal diseases and postharvest fruit fungal rot. The key aspects in the success of this technology for disease control are related to biosafety and environmental impact of biocontrol agents, the traceability and fate in the environment and food chain, the improvement by physiological, genetic engineering or the use of mixtures or formulations as well as the industrial production and development of delivery systems for treatment application to trees.
\end{abstract}

Communicated by D. Treutter.

A. Bonaterra $(\bowtie) \cdot$ E. Badosa · J. Cabrefiga · J. Francés ·

E. Montesinos

Institute of Food and Agricultural Technology-XaRTA-

CIDSAV, University of Girona, Campus Montilivi s/n,

17071 Girona, Spain

e-mail: anna.bonaterra@udg.edu
Keywords Microbial pesticides - Biosafety · Environmental impact · Physiological improvement . Genetic engineering · Formulation · Delivery

\section{Introduction}

Microbial pesticides are products used to control plant diseases made from beneficial microorganisms or the metabolites they produce. Many products composed of viruses, bacteria, yeast, and fungi are marketed worldwide and obviously play an important role in sustainable agriculture although their practical use is at present limited (Ragsdale and Sisler 1994; Montesinos 2003; Montesinos and Bonaterra 2009). In the past, several authors have argued that the main advantages of microbial pesticides compared to chemical products are (a) the absence of harmful residues, (b) the environmental friendly nature, and (c) the low production cost (Cook and Baker 1983). However, at present, there are scientific evidences indicating that these advantages are not always achieved. Their main disadvantages are, (a) the very high specificity against the target disease and pathogen that may require multiple microbial pesticides to be used, and often (b) the variable efficacy due to the influences of various biotic and abiotic factors, because microbial pesticides are living organisms.

The experience accumulated over several decades of research have been successful and hundreds of strains of microorganisms have been reported as active in the control of different pomefruit tree pathogens, such as bacteria and fungi causing aerial or root diseases, or are effective against postharvest rot of fruits (Table 1). Strains of microorganisms used to control pomefruit tree diseases are distributed mainly among Gram-negative bacteria such as Pseudomonadaceae and Gram-positive bacteria such as Bacillaceae, and there 
are also many representatives of yeasts and fungi especially within Basidyomicota (Montesinos and Bonaterra 2009).

\section{Mechanisms of action}

Knowledge of the mechanisms of biocontrol in a microbial pesticide is a key factor to achieve an efficient reduction of the pathogen in their host. Several strains cover a single mechanism and other use a combination of them. Antibiosis against plant-pathogenic bacteria and fungi affecting fruit trees is very common. There are examples for a role of cyclolipopeptides like fengycins produced by Bacillus subtilis in disease reduction to protect wounded apple fruits against gray mold disease caused by Botrytis cinerea (Ongena et al. 2005), phenolic antifungal compounds like pyrrolnitrin in Pseudomonas cepacia (Janisiewicz and Roitman 1988), bacteriocins like herbicolin and pantocins in Pantoea agglomerans and Pantoe vagans (Ishimaru et al. 1988; Wright et al. 2001; Smits et al. 2010) or lytic enzymes in several yeast and fungi like in Trichoderma harzianum against Penicillium expansum in apple (Batta 2004). Competitive exclusion of the pathogen from sites of infection by better use of nutrients and colonization than the pathogen is also a common mechanism that can accompany other mechanisms, and is considered as the major modes of action by which microbial agents control pathogens causing postharvest decay of pome fruits (Sharma et al. 2009) and also in fireblight control (Cabrefiga et al. 2007). Several hyperparasites, especially abundant among the yeast and fungi like Pichia and Trichoderma, interact directly and degrade the fungal cell, or exert antagonism through antimicrobial compounds, develop hyperparasitism or directly attach to the pathogen cells, interfere with pathogen signals, or induce resistance into the plant host (Harman 2006). A special case of parasitism is exemplified by the application of fungal viruses against certain fungi and bacteriophages that are lytic to several plant pathogenic bacteria (Jones et al. 2007; Ghabrial and Suzuki 2009). Some bacteria and fungi are able to induce defense responses in plants, by producing either elicitors (e.g. cell wall components) or messenger molecules (e.g. salicylic acid) (Spadaro and Gullino 2004). Finally, some BCAs can inhibit plant pathogens by degradation of chemical signal messengers necessary for quorum sensing (e.g. acyl homoserine lactones) used to start the infection process by the pathogen (Molina et al. 2003).

\section{Regulatory issues for commercialization of microorganisms as biocontrol agents}

The priority objectives in the area of plant protection products shift toward a rational use of pesticides and a reduction in the number of registered active ingredients to those that are more selective, less toxic, and lacking negative environmental impact (Gullino and Kuijpers 1994). Therefore, several countries have undertaken regulatory changes in pesticide registration requirements, given that consumer health and environmental preservation prevail over productive or economic considerations. In the European Union (EU), the availability of BCA products for agricultural use is limited by the requirements of the legislation on registration of new plant biologicals, which affects some of the more interesting biological control agents (Fravel et al. 1999; Mathre et al. 1999; EC 2000; Harman 2000; Montesinos 2003; Montesinos and Bonaterra 2009). The registration procedure generally requires detailed dossiers accounting for scientific data on microorganism identity, biological properties, efficacy, specific analytical methods, residues, traceability, and potential adverse effects on human health and non-target organisms. Furthermore, specific requirements may change when an authorization application considers the microorganism as a biocide or a plant enhancer. Several microorganisms have been registered in different countries and in the EU as biocontrol agents of pomefruit tree diseases covering mainly fire blight, soil-borne fungal diseases and postharvest fruit fungal rot (Table 2) (http://ec.europa.eu/food/ plant/protection/evaluation/index_en.htm).

\section{Biosafety and environmental impact}

Before commercialization and delivery of BCAs to agricultural environments their biosafety, and behaviour and impact on ecosystems has to be evaluated. Regulations in many countries now require an analysis of environmental impact as part of an application for registration and commercial development not only of genetically modified biocontrol agents. Several features of the released biocontrol agents have to be considered for an adequate assessment of adverse effects on the ecosystem. Some examples are the establishment and survival, dispersal, genetic stability and horizontal genetic transfer, effects on the resident microbiota and fauna (pathogenicity, virulence, allergenicity and toxicity towards humans, animals and plants), and availability and applicability of effective containment systems if they are required.

For biosafety testing of any organisms released into the environment, validation of predictions made in the laboratory by post-release field monitoring of environmental impacts is crucial. Well-designed ecological monitoring programmes will provide data, which can help regulators as well as future applicants based on similar monitored cases (van Elsas et al. 1998). In this context, it is necessary to have methods for specific analysis at strain level, which are 
Table 1 Biocontrol agents of bacterial and fungal pomefruit tree pathogens and diseases

\begin{tabular}{|c|c|c|}
\hline Microbial biocontrol agent & Disease & References \\
\hline Agrobacterium radiobacter & Crown gall (Agrobacterium tumefaciens) & Vicedo et al. (1993) \\
\hline Acremonium breve & Gray mold (Botrytis cinerea) & Janisiewicz (1988) \\
\hline \multirow[t]{2}{*}{ Aureobasidium pullulans } & Gray mold (B. cinerea) & Ippolito et al. (2000); Castoria et al. (2001) \\
\hline & Blue mold (Penicillium expansum) & Ippolito et al. (2000); Castoria et al. (2001) \\
\hline \multirow[t]{3}{*}{ Bacillus subtilis } & Fireblight (Erwinia amylovora) & Broggini et al. (2005) \\
\hline & Apple ring rot (Botryosphaeria berengeriana) & Liu et al. (2009) \\
\hline & Phytophthora cactorum & Utkhede et al. (2001) \\
\hline \multirow[t]{2}{*}{ Bacillus pumilus } & Apple scab (Venturia inaequalis) & Kucheryava et al. (1999) \\
\hline & Gray mold (B. cinerea) & Mari et al. (1996) \\
\hline Bacillus licheniformis & Gray mold (Botrytis mali) & Jamalizadeh et al. (2008) \\
\hline \multirow[t]{3}{*}{ Burkholderia cepacia } & Blue mold $(P$. expansum $)$ & Janisiewicz and Roitman (1988) \\
\hline & Mucor rot (Mucor piriformis) & Janisiewicz and Roitman (1988) \\
\hline & Gray mold (B. cinerea) & Janisiewicz and Roitman (1988) \\
\hline \multirow[t]{2}{*}{ Candida guilliermondii } & Blue mold ( $P$. expansum) & McLaughlin et al. (1990) \\
\hline & Gray mold $(B$. cinerea $)$ & McLaughlin et al. (1992) \\
\hline \multirow[t]{2}{*}{ Candida oleophila } & Penicillium rot $(P$. expansum $)$ & El-Neshawy and Wilson (1997) \\
\hline & Gray mold $(B$. cinerea $)$ & Mercier and Wilson (1994) \\
\hline \multirow[t]{3}{*}{ Candida sake } & Penicillium rot $(P$. expansum $)$ & Viñas et al. (1996) \\
\hline & Gray mold (B. cinerea) & Viñas et al. (1998) \\
\hline & Rhizopus rot (Rhizopus nigricans) & Viñas et al. (1998) \\
\hline Candida saitoana & Apple fruit decay ( $P$. expansum; B. cinerea) & El Ghaouth et al. (2000) \\
\hline \multirow[t]{3}{*}{ Cryptococcus albidus } & Mucor rot $(M$. piriformis $)$ & Roberts (1990) \\
\hline & Gray mold (B. cinerea) & Fan and Tian (2001) \\
\hline & Blue mold ( $P$. expansum) & $\begin{array}{l}\text { Chand-Goyal and Spotts (1996); } \\
\text { Calvo et al. (2003) }\end{array}$ \\
\hline Cryptococcus flavus & Mucor rot (M. piriformis) & Roberts (1990) \\
\hline Cryptococcus humicola & Gray mold $(B$. cinerea $)$ & Filonow et al.(1996) \\
\hline \multirow[t]{4}{*}{ Cryptococcus laurentii } & Bitter rot (Glomerella cingulata) & Blum et al. (2004) \\
\hline & Mucor rot (M. piriformis) & Roberts (1990) \\
\hline & Gray mold (B. cinerea) & $\begin{array}{l}\text { Zhang et al. (2005); Chand-Goyal } \\
\text { and Spotts (1997) }\end{array}$ \\
\hline & Blue mold ( $P$. expansum $)$ & Zhang et al. (2003) \\
\hline Kloeckera apiculata & Gray mold (B. cinerea) & McLaughlin et al. (1992) \\
\hline \multirow[t]{2}{*}{ Metschnikowia pulcherrima } & Blue mold ( $P$. expansum) & Spadaro et al. (2002) \\
\hline & Gray mold (B. cinerea) & Spadaro et al. (2002) \\
\hline \multirow[t]{4}{*}{ Pantoea agglomerans } & Fireblight (E. amylovora) & Wilson et al. (1992) \\
\hline & Penicillium rot $(P$. expansum $)$ & Nunes et al. (2002); Francés et al. (2006) \\
\hline & Phytophthora cactorum & Utkhede and Smith (1997) \\
\hline & Rhizopus rot ( $R$. nigricans) & Nunes et al. (2001) \\
\hline \multirow[t]{2}{*}{ Pseudomonas fluorescens } & Fireblight (E. amylovora) & $\begin{array}{l}\text { Wilson and Lindow (1993); } \\
\text { Cabrefiga et al. (2007) }\end{array}$ \\
\hline & Gray mold (Botrytis spp.) & Mikani et al. (2008) \\
\hline \multirow[t]{2}{*}{ Pseudomonas syringae } & Blue mold ( $P$. expansum) & Janisiewicz (1987); Zhou et al. (2001) \\
\hline & Gray mold $(B$. cinerea $)$ & Zhou et al. (2001) \\
\hline \multirow{2}{*}{ Rahnella aquatilis } & Gray mold (B. cinerea) & Calvo et al. (2007) \\
\hline & Blue mold ( $P$. expansum) & Calvo et al. (2007) \\
\hline Reoviridae (W370dsRNA) & Rosellinia necatrix & Kanematsu et al. (2004) \\
\hline Rhodotorula glutinis & Apple fruit decay $(P$. expansum $; B$. cinerea $)$ & Zhang et al. (2009) \\
\hline Trichoderma harzianum & Gray mold (B. cinerea) & Batta, (2004) \\
\hline \multirow[t]{2}{*}{ Trichoderma spp } & P. cactorum & Smith et al. (1990) \\
\hline & Armillaria rot (Armillaria mellea) & Elkins et al. (1998) \\
\hline
\end{tabular}


Table 2 Strains of biocontrol agents in commercial microbial biofungicides and bactericides registered in the EU

\begin{tabular}{|c|c|c|}
\hline Active ingredient & Target pathogen/disease & Host \\
\hline $\begin{array}{l}\text { Bacillus subtilis strain QST } \\
\quad 713\end{array}$ & $\begin{array}{l}\text { Bacteria (fire blight) and fungal root diseases, } \\
\text { Alternaria, Aspergillus, Venturia, grey mould }\end{array}$ & Grape, pome and stone fruits, horticultural crops \\
\hline $\begin{array}{l}\text { Coniothyrium minitans strain } \\
\text { CON/M/91-08 (DSM 9660) }\end{array}$ & $\begin{array}{l}\text { Sclerotinia } C \text {. minitans is a highly specialised } \\
\text { hyperparasite. Its host range is restricted to certain } \\
\text { sclerotia-forming species within the Ascomycotina } \\
\text { and Deuteromycotina }\end{array}$ & Horticultural crops (soil decontamination) \\
\hline $\begin{array}{l}\text { Gliocladium catenulatum } \\
\text { strain J1446 }\end{array}$ & $\begin{array}{l}\text { Pythium, Rhizoctonia, Phytophthora, Fusarium, } \\
\text { Didymella, Botrytis, Verticillium, Alternaria, } \\
\text { Cladosporium, Helminthosporium and Penicillium }\end{array}$ & $\begin{array}{l}\text { Vegetables, herbs, strawberries, ornamentals and } \\
\text { stored products }\end{array}$ \\
\hline $\begin{array}{l}\text { Phlebiopsis gigantea } 14 \\
\text { strains }\end{array}$ & Heterobasidion annosus & Coniferous trees \\
\hline $\begin{array}{l}\text { Pseudomonas chlororaphis } \\
\text { strain MA } 342\end{array}$ & Seedborne fungi & $\begin{array}{l}\text { Fieldgrown monocotyledonous crops (oat, rye, } \\
\text { durum, barley, wheat triticale) }\end{array}$ \\
\hline $\begin{array}{l}\text { Pythium oligandrum Strain } \\
\text { M1 }\end{array}$ & $\begin{array}{l}\text { Soilborne pathogenic fungi and Alternaria and } \\
\text { Sclerotium }\end{array}$ & Oil-seed rape in the field \\
\hline $\begin{array}{l}\text { Streptomyces K61 (formely } \\
\text { S. griseoviridis) }\end{array}$ & Root rot, grey mould and foot decay & $\begin{array}{l}\text { Ornamentals, vegetables and herbs, under protection } \\
\text { and outdoors }\end{array}$ \\
\hline $\begin{array}{l}\text { Trichoderma asperellum } \\
\text { (formerly T. harzianum) } \\
\text { strains ICC012, T11 and } \\
\text { TV1 }\end{array}$ & $\begin{array}{l}\text { Soil-borne fungal plant pathogens (e.g., Pythium spp., } \\
\text { Phytophthora spp., Sclerotinia spp., Sclerotium spp., } \\
\text { Thielaviopsis basicola, Rhizoctonia spp., } \\
\text { Verticillium spp.) }\end{array}$ & $\begin{array}{l}\text { Horticulture, forestry, viticulture, nursery, } \\
\text { glasshouse, greenhouse, open fields, protected } \\
\text { crops, home gardening, house plants, ornamentals }\end{array}$ \\
\hline $\begin{array}{l}\text { Trichoderma atroviride } \\
\text { (formerly T. harzianum) } \\
\text { strains IMI } 206040 \text { and T11 }\end{array}$ & Soil-borne fungal plant pathogens & $\begin{array}{l}\text { Strawberries outdoors and in greenhouse. On } \\
\text { ornamental trees in the field }\end{array}$ \\
\hline $\begin{array}{l}\text { Trichoderma gamsii (formerly } \\
\text { T. viride) strain ICC } 080\end{array}$ & $\begin{array}{l}\text { Soil-borne fungal plant pathogens (e.g., Pythium spp., } \\
\text { Phytophthora spp., Sclerotinia spp., Sclerotium spp., } \\
\text { Thielaviopsis basicola, Rhizoctonia spp., } \\
\text { Verticillium spp.) }\end{array}$ & $\begin{array}{l}\text { Horticulture, forestry, viticulture, nursery, } \\
\text { glasshouse, greenhouse, open fields, protected } \\
\text { crops, home gardening, house plants, ornamentals }\end{array}$ \\
\hline $\begin{array}{l}\text { Trichoderma harzianum } \\
\text { strains T-22 and ITEM } 908\end{array}$ & Soil-borne fungal plant pathogens & $\begin{array}{l}\text { Horticulture, forestry, viticulture, nursery, } \\
\text { glasshouse, greenhouse, open fields, protected } \\
\text { crops, home gardening, house plants, ornamentals }\end{array}$ \\
\hline $\begin{array}{l}\text { Trichoderma polysporum } \\
\text { strain IMI } 206039\end{array}$ & Soil-borne fungal plant pathogens & $\begin{array}{l}\text { Horticulture, forestry, viticulture, nursery, } \\
\text { glasshouse, greenhouse, open fields, protected } \\
\text { crops, home gardening, house plants, ornamentals }\end{array}$ \\
\hline $\begin{array}{l}\text { Verticillium albo-atrum } \\
\text { (formerly V. dahliae) strain } \\
\text { WCS850 }\end{array}$ & Dutch elm disease & Elm \\
\hline
\end{tabular}

This table contains only products currently registered (updated 9/16/2011). Products that are pending of decision and temporarily authorized in certain countries are not listed

not available in most BCAs. Similarly, there is a need for methods to analyze the population of autochthonous microbiota to estimate the qualitative and quantitative alterations in the microbial community structure that the released BCAs may cause. This is probably the most difficult aspect of the determination of the biosafety of a release, since a variety of assessments are required to study microbial diversity into the tree environment like DGGE fingerprinting or other molecular methods.

Toxicological studies in mammals, including acute toxicity tests, are performed to guarantee safety to consumers and handlers of the microbial pesticides, especially if cases of clinical opportunistic infections are reported or if certain secondary metabolites of concern are produced.
However, risk evaluation is not a simple task, because the risk of nontarget effects for a given microorganism is estimated from the intrinsic toxicity-pathogenicity level, the degree of exposure, and the susceptibility of the possible receiver. Most microbial pesticide strains meet all biosafety rules. However, in a few cases, there are uncertainties regarding the potential risk, because in some species of BCAs opportunistic human pathogen strains have been reported. Phenotypic and genotypic studies performed using strains of Burkholderia cepacia (Parke and GurianSherman 2001), Pseudomonas putida (Aumeran et al. 2007), Pantoea agglomerans (Rezzonico et al. 2009), and Aureobasidium pullulans (Gostincar et al. 2011) did not reveal differences between environmental and clinical 
isolates, demonstrating that the capacity to grow freely in natural habitats and cause opportunistic infections can be encoded within any given strain. Interestingly, some of these microorganisms are widespread in nature and are inhabitants on the surface of many plants (Leben 1965). These uncertainties are the reason for specific and differing regulations on risk classification of microorganisms among countries.

A formal assessment of safety has been established by European Food Safety Authority (EFSA) that is based in a "Qualified Presumption of Safety (QPS)" (EFSA 2007) consisting on four pillars (identity, body of knowledge, possible pathogenicity and end use). Any strain of microorganism, the identity of which could be unambiguously established and assigned to a QPS group, would be freed from the need for further safety assessment other than satisfying any qualifications specified. Microorganisms not considered suitable for QPS remain subject to a full safety assessment (http:// www.efsa.europa.eu/en/panels/pesticides.htm).

\section{Traceability and fate in the environment}

Monitoring the fate and behaviour of a released microorganism strain in the environment is necessary to perform risk assessment studies on traceability, residue analysis, and environmental impact required for registration of microbial pesticides (De Clercq et al. 2003; Montesinos 2003). These legal requirements need the use of monitoring methods that can accurately identify the released strain, distinguish it from the native species into the microbial community and track its population dynamics over time.

Several methods can be used in field studies to assess the fate of the target microorganism (Fig. 1). The classical culture-based methods consist of growth on selective media or media composed with selectable markers (antibiotic or fungicide resistance, nutritional complementation, induced mutations which confer particular colony morphology). If a selective medium is not available, identification of the BCA at the strain level must be achieved by other means, such as morphological analysis, immunological assays (ELISA tests), or molecular methods, such as probe-hybridization of the $16 \mathrm{~S}$ or $18 \mathrm{~S}$ rDNA sequences, or examination of microsatellite markers (Ryder 1995; Plimmer 1999). The amount of time needed to develop and perform these tests and their high costs are the major constraints of most of these techniques. The use of culture independent tools like fluorescent antibodies or fluorescently labelled oligonucleotide probes, or to transform the BCA with fluorescence ( $g f p$ ) or bioluminiscence (lux) reporter genes is advantageous for tracking microbial strains because allow the localization and visualization of microbial cells in situ, interacting with the host. However, the use of heterologous genes converts the BCA into a genetically modified microorganism, carrying severe restrictions for its release into the environment due to the possibility of persistence in the environment (Steinhäuser 2001). PCR-based methods designed using genotypic markers (SCAR fragments) can be developed, and are reliable and quick to develop a PCR procedure (Pujol et al. 2006). However, conventional PCR technique is suited for identification of strains but does not allow quantitative analyses, by contrast real-time PCR (qPCR) do and is also very repetitive and reliable (Schena et al. 2004). A problem of conventional qPCR is that does not discriminate between viable and nonviable microorganisms. A BIO-PCR method, that combines a biological preamplification on growth medium with direct PCR, can specifically detect viable cells of a target microorganism, but do not quantify the population (Schaad et al. 1995). Interestingly, the combination of qPCR with plate-counting methods provided a tool to analyze the population behaviour in terms of the proportion of viable cells (Pujol et al. 2006, 2007). Moreover determination of viable cells can be done by reverse transcription (RT) coupled to qPCR for which complete DNA digestion is required prior to the amplification reaction. Nucleic acid sequencebased amplification (NASBA) (Compton 1991) is a very promising alternative method, since it can selectively amplify mRNA even in the presence of genomic DNA. The
CULTURE BASED METHODS

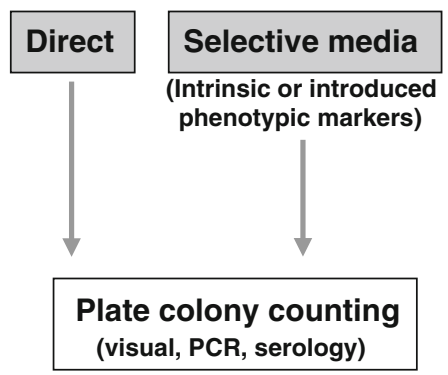

CULTURE INDEPENDENT METHODS

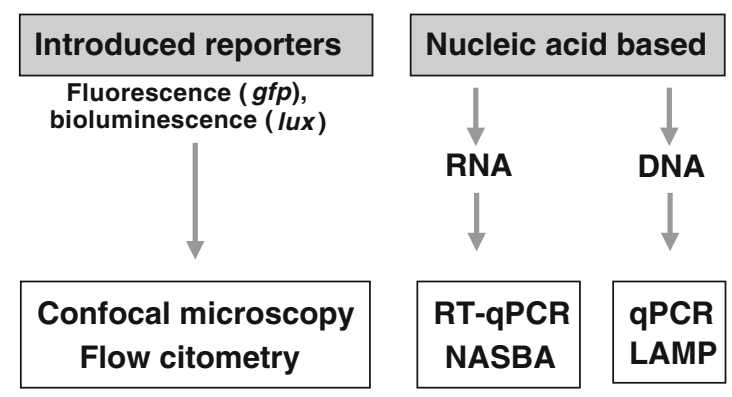

Fig. 1 Quantitative analysis methods of biocontrol agents at strain level 
NASBA product can be detected using molecular beacons (QNASBA). An alternative is loop-mediated isothermal amplification (LAMP) (Tomita et al. 2008) that has been used to detect Erwinia amylovora in pomefruit tree surface (Temple and Johnson 2011), but has not been used in BCAs and is still under validation.

The fate and behaviour of released BCAs in the natural environment have been studied not only in soil, rhizosphere and in the phyllosphere (flowers, leaves, fruits), but also in postharvest of fruit.

Studies performed in natural soils concluded that population sizes of artificially introduced bacteria decline more or less rapidly following inoculation, and growth of introduced populations in microbiologically undisturbed soils is a rare phenomenon (van Veen et al. 1997). In addition, population declines were observed for artificially introduced BCAs in the rhizosphere. For instance, strains of Pseudomonas fluorescens CHAO, F113 and Pf153 can colonize plant roots initially at levels of about $10^{7}-10^{8} \mathrm{CFU} \mathrm{g}^{-1}$, but decline after a few weeks. Interestingly different behaviour between strains was observed because Pf153 is more persistent in the rhizosphere than the other two strains (Haas and Défago 2005). BCAs behaviour in soil and rhizosphere are affected by formulation, application techniques and environmental conditions (Hase et al. 2001).

Similarly, in the phyllosphere the fate of BCA also depends greatly on environmental conditions. For example, Pseudomonas fluorescens EPS62e introduced on apple and pear trees in orchards under Mediterranean climatic conditions established high and stable population levels in blossom and fruit calyx end, whereas was unable to colonize leaves for long time. The strain dominated the microbial communities of blossoms, representing up to $100 \%$ of the culturable population and spread moderately in the orchard, being detected in non-treated flowers of trees 15-35 $\mathrm{m}$ from the inoculation site (Pujol et al. 2007). Moreover, other works performed in the phyllosphere confirmed that key factors affecting the establishment of BCAs on floral surfaces are the inoculum preparation, the temperature and the bloom stage at the treatment time. For instance, spraying of P. vagans C9-1, P. fluorescens A506 (Nuclo et al. 1998) or Bacillus subtilis BD170 (Broggini et al. 2005) in trees under field conditions resulted in efficient primary colonisation of pistils in flowers that were open at the time of treatment. Subsequent bacterial dissemination (secondary colonisation) of flowers that were closed or at bud stage at the time of treatment was observed (Johnson et al. 2000).

In addition, several studies were performed on fruit surface under postharvest conditions in which the adaptation of BCAs at storage conditions (low temperature and even ultra low oxygen concentration) was confirmed. This was the case of Candida oleophila strain $\mathrm{O}$ that maintain a

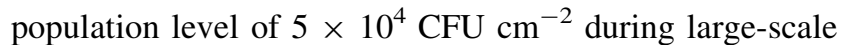
experiments on apples (Massart et al. 2005).

The use of combinations of methods of analysis provides information on the population viability such as in the case of using real-time PCR and CFU counting methods. A rise in the population of $P$. fluorescens EPS62e and a coincidence between both techniques was observed when conditions were optimal (flowers colonization), while differing and decreasing values were observed in leaves, where environmental conditions were unfavourable for this strain (Pujol et al. 2006) (Fig. 2).

\section{Improvement of biocontrol agents}

One of the major limitations of biological control is the high variability in the efficacy of one test to another, depending on biotic (host species, nutritional status, pathogen) and abiotic (temperature, wetness, relative humidity) factors (Johnson et al. 2000; Lugtenberg and Leveau 2007; Sundin et al. 2009). The lack of performance in microbial pesticides is usually due to difficulties of the BCA to colonize and survive in the environment in which it applies, because its fitness is limited under field conditions. Specially the phyllosphere and to a lesser extent the rhizosphere, are environments subject to large fluctuations of space-time environmental and phenological conditions, with a well established indigenous microbiota that is difficult to be displaced by non-native microorganisms. Increasing the competitiveness of a BCA in the plant environment is a key step in improving its biocontrol ability and different strategies can be used.

A suitable strategy is based in the nutritional enhancement of the BCA to promote its multiplication in the plant environment and/or the inhibition of growth of the competing microorganisms. The use of certain chemicals in combination with a BCA strain that suppressed the competing or antagonistic indigenous microbiota, or the addition of nutrients in formulations that are more efficiently used by the BCA than by the pathogen are strategies reported to enhance survival and adaptability as well as biocontrol efficacy in several fungal plant pathogens (Janisiewicz et al. 1992; Moënne-Loccoz et al. 1999; El Ghaouth et al. 2000; Guetsky et al. 2002; Druvefors et al. 2005). For instance, the efficiency of biocontrol of fireblight infections by $P$. fluorescens 62 e was improved by addition of glycine and Tween 80 , with no effect on E. amylovora infection potential (Cabrefiga et al. 2011). Similarly, the use of some chemical compounds that are promoters in the rhizosphere have been used to selectively induce in situ expression of a beneficial gene (e.g., biocontrol), like the effect of proline in a P. fluorescens strain (van Veen et al. 1997). 


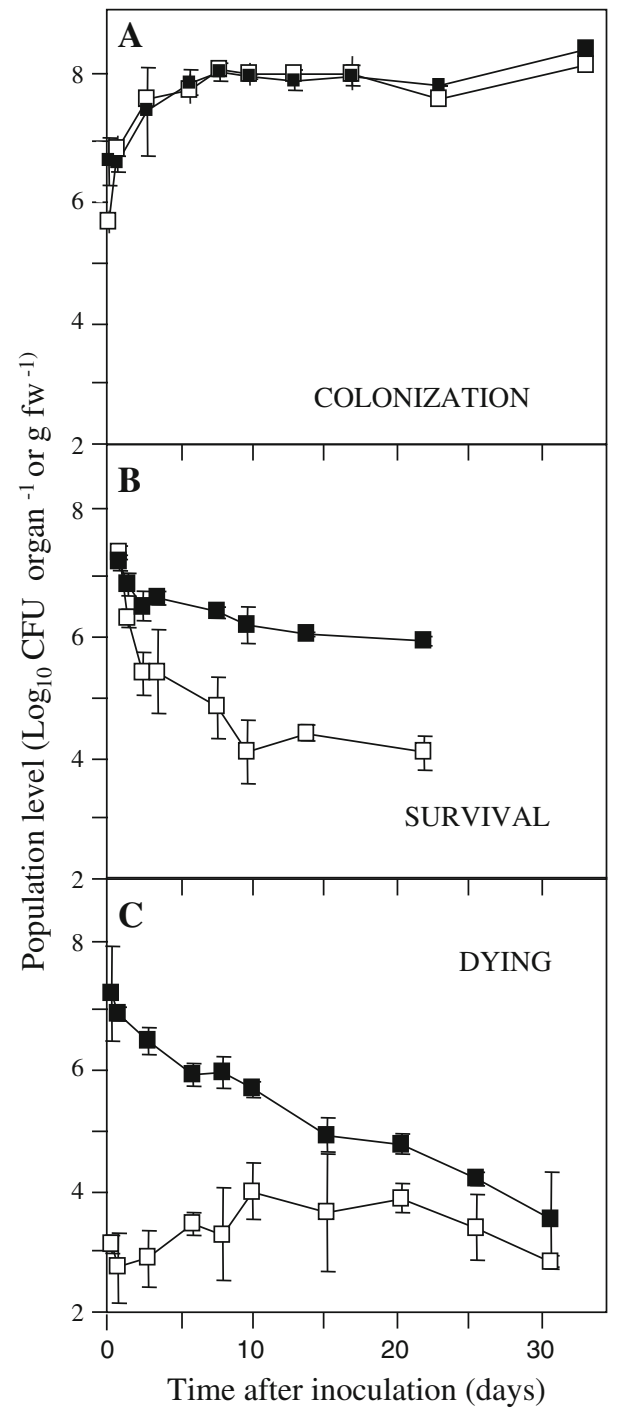

Fig. 2 Population dynamics of $P$. fluorescens $62 \mathrm{e}$ estimated by realtime PCR (filled squares) and plating (open squares) on apple flowers under field in spring (a), on apple leaves under greenhouse (b) and in leaves in field conditions in summer (c). (Modified from Pujol et al. 2006)

Another strategy is the modification of the physiology of the BCA to adapt themselves to adverse situations after application in natural environments (soil, rhizosphere, phyllosphere). Several microorganisms survive under osmotic stress, through a physiological process of osmoadaptation consisting of the intracellular accumulation of compatible solutes (including sugars, polyols, heterosides, amino acids and amino acid derivatives). This process can be induced by cultivation under suboptimal conditions and allows cells to tolerate, not only drought or salinity, but also freezing and high temperatures as well as improving the ecological fitness (Csonka and Hanson 1991; Miller and Wood 1996; Welsh and Herbert 1999). The physiological adaptation to unfavourable conditions has been used in several BCAs like Pantoea agglomerans EPS125,

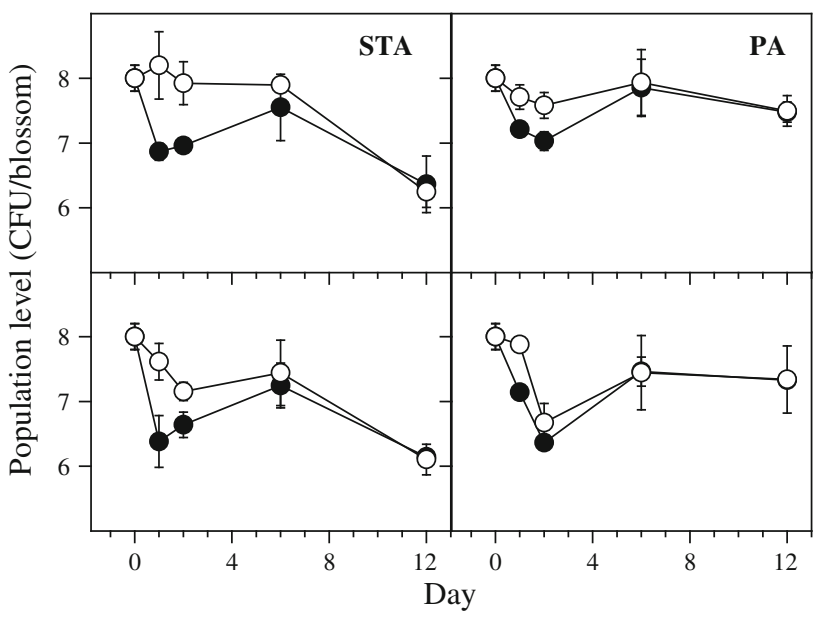

Fig. 3 Effect of physiological adaptation (osmoadaptation and nutritional enhancement) in the fitness of $P$. fluorescens EPS62e in apple flowers under field conditions. Blossoms were treated under field conditions with standard EPS62e cells (STA) or with physiologically adapted (PA) EPS62e cells and total (open circle, real-time PCR) and culturable (filled circle, plate counting method) population level was assessed. (Modified from Cabrefiga et al. 2011)

Pseudomonas fluorescens EPS62e (Bonaterra et al. 2005, 2007) and Candida sake CPA-1 (Teixidó et al. 1998) to induce stress tolerance by combination of saline osmotic stress and osmolyte amendment or by modifying nutrient status and water stress, respectively, and to increase the efficiency of biocontrol.

The combination of osmoadaptation with other strategies like nutritional enhancement also improves the fitness of BCAs on aerial plant surfaces. A procedure of physiological adaptation using both strategies to increase colonization and survival in the phyllosphere of Rosaceous plants has been developed to improve fitness and efficacy of the fire blight BCA, P. fluorescens EPS62e (Fig. 3) (Cabrefiga et al. 2011). A ready-to-use formulation with the physiologically adapted BCA can be easily prepared by growing the BCA in a bioreactor with a suitable broth culture amended with salts and osmolytes (osmoadaptation), and the harvested cells mixed with the specific nutrient (nutritional enhancement) to made a liquid or dried formulation (Montesinos and Bonaterra 2009).

Another strategy used to improve biological control is to combine antagonists with different mechanisms of biocontrol (Janisiewicz 1988; Spadaro and Gullino 2005; Stockwell et al. 2011). Combinations of strains, if they are compatible, permit a more extensive colonization of the phytosphere and increase the expression of important biocontrol traits affecting the pathogen under a broader range of environmental conditions than strains applied individually. For example, the combination of two strains of $P$. fluorescens increased efficacy in control of Phytophthora root rot of strawberry and decreased variability within each treatment (Agustí et al. 2011) (Fig. 4). 
The improvement of BCAs can also be achieved by means of genetic modification. Genetic improvement has the advantage of incorporating sustainable features in the progeny of the BCA. Breeding based strategies can be used to over express genes involved in the production of pre-existing metabolites or to introduce new genes, or develop strains that produce higher levels of antimicrobial compounds, or perform genetic manipulations, which alter the time of production (Walsh et al. 2001). Several genetic modifications have been performed to enhance biological control in the rhizosphere, including the overproduction of antimicrobial compounds such as in T. harzianum or in P. fluorescens CHAO (Flores et al. 1997; Girlanda et al. 2001).

The introduction of genetically engineered strains is limited by EU legal regulations and it has been suggested to pose potential hazard to the environment as well as to sensitive organisms. In the case of the use of genetically modified BCAs, the requirements of EU legislation for environmental release and commercial use are very strict and comprehensive, and include various types of environmental impact assessment and risk analysis for both the BCA and the substances it produces. Although the hazards can potentially be minimized by a careful choice of the genetic construction, by opting for a chromosomal insertion instead of a plasmid-borne gene, and by the delivery system, minimizing translocation and dispersal (van Elsas and Migheli 1999). Similarly, biotechnology can be used to emphasize useful traits in the rhizosphere of plants that include exudates that increase nutrient accessibility, minimize stress or that encourage the persistence of beneficial microorganisms. Thus, transgenic plants and microorganisms can be engineered to exude exogenous compounds that improve plant nutrition, repress pathogenic microbes

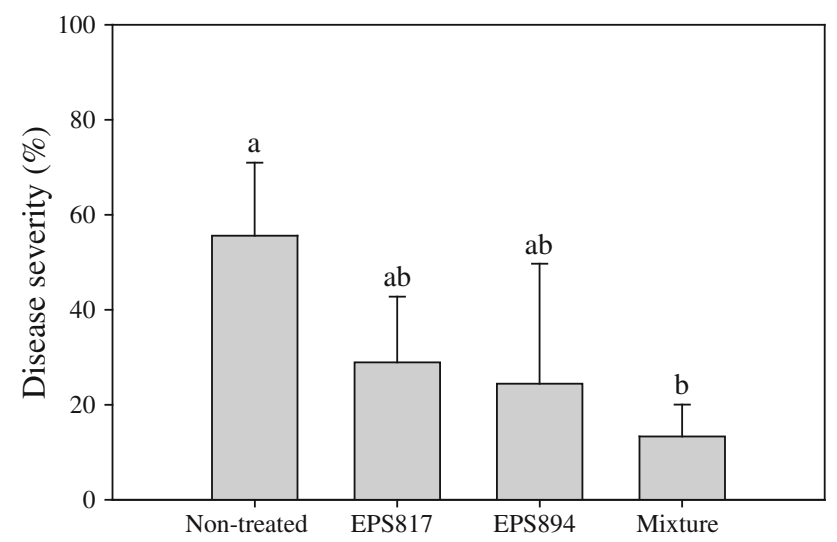

Fig. 4 Effect of P. fluorescens strains EPS817, EPS894 and their mixture on Phytophthora cactorum disease severity in strawberry plants of cv. Diamante. Values are means of three replicates of five plants. Means headed by different letters are significantly different $(P \leq 0.05)$ according to Duncan's test. (Modified from Agustí et al. 2011) and minimize the consequences of biotic or abiotic stresses (Ryan et al. 2009).

\section{Production and formulation}

Commercial exploitation of selected strains requires suitable industrial production and formulation to increase shelf-life and retain biocontrol activity similar to that of fresh cells of the agents (Powell and Jutsum 1993; Burgues and Jones 1998). To produce BCAs, proper methods of industrial scale-up and fermentation have to be developed although there are out of the scope of this paper. Similarly, the development of a suitable formulation methodology is essential for obtaining long shelf-life and different liquid or dried formulations have been used in marketed microbial pesticides. Liquid formulation products consist of biomass suspensions in water oils or emulsions with retained viability and efficacy for several months, but generally should be stored and distributed under refrigerated conditions (Abadias et al. 2003). Dry formulation products include wettable powders (to be applied as a suspension in liquid), dusts (to be applied dry) and granules (Schisler et al. 2004). All of these dry formulated products can be easily transported and stored but must be dehydrated to achieve a stable product. However, due to cell damage during dehydration, loss of cell viability can be of several orders of magnitude (Rhodes 1993). Thus, exogenous protectants have to be added to allow the preservation of cell viability during dehydration. Various groups of substances, such as sulfoxydes, alcohols and their derivatives, monosaccharides and polysaccharides, amino acids, peptides, glycoproteins and compounds have been shown protective action against dehydration damage. In addition, the type of dehydration process has an influence on survival. Drying can be accomplished by a number of means including freeze-drying, spray-drying and fluidized bed-drying. Freeze-drying is a common technique in industry that is the least damaging method for drying microorganisms and resulted in formulations with log-term stability. However, it could be a too expensive alternative for cost-sensitive large-scale productions. In contrast, spray-drying is a more economic method but stressful for cells since it involves extreme water loss and temperature gradients. A similar technique, the fluidized-bed drying have been used for some applications, especially for desiccation-tolerant yeast, which is also economic and generally considered less stressful than spray-drying (Larena et al. 2003).

Several marketed bacterial inoculants are peat-based formulations used to coat pellets for sowing to be applied in soils, or encapsulated formulations in which the active ingredient was surrounded with a protective inert layer. This layer can consist of polymers like alginate, 
carragenan, or cellulose (Bashan et al. 2002). The encapsulation of microorganisms protects them against many environmental stresses and releases them to the phythosphere gradually. Finally, different amendments have been used in microbial pesticide formulations that improve the properties of the formulated BCA (chemical filters to prevent ultraviolet radiation damage, wetting agents, specific nutrients) (Schisler et al. 2004).

\section{Application and delivery systems}

Microbial pesticides are applied following inoculative, augmentative, or inundative strategies. The application can be local using sticks or tablets near the root system, by seed coating or root bacterization of seedlings before transplanting, by using helper insects for dispersion; and by spraying or drenching plants with the product. In the case of postharvest disease control, the fruit can be treated in preharvest or postharvest as is done with chemical pesticides. The basic principle is to introduce the BCA in the plant ecosystem, to allow its multiplication or survival near or within the specific pathogen entry sites in the host plant. The inoculative and augmentative strategy consist of the application of a low initial population of the BCA, which then multiplies and achieves effective population levels that control the pathogen. In contrast, the inundative strategy is based on the same principle that in chemical pesticides, and the BCAs are applied at an effective concentration, generally high (e.g. $10^{7}-10^{8} \mathrm{CFU} \mathrm{mL}{ }^{-1}$ ). In all cases, the efficiency of BCA in the control of pathogens is strongly dose-dependent, because it is affected by the relative amounts of pathogen and BCA in the plant, as well as on pathogen aggressiveness (Montesinos and Bonaterra 1996; Francés et al. 2006). To ensure covering a wide range of conditions of applicability in practice, a dose of around $10^{8} \mathrm{CFU} \mathrm{mL}{ }^{-1}$ is recommended for bacterial BCAs and $10^{7} \mathrm{CFU} \mathrm{mL} \mathrm{m}^{-1}$ for fungi or yeast.

\section{Future prospects}

There has been a tremendous increase in knowledge and technology in the past years on BCAs development, and a great part of the limitations have been addressed. Often, microbial pesticides are conceived by researchers as the single technology in the future scenario of plant protection. However, biological control has only significance as a part of the complementary measures that configure a modern integrated crop protection strategy. The challenge now is to compatibilize and coordinate the use of microbial pesticides with other measures especially chemical insecticides, fungicides or bactericides addressed to control the many biotic agents limiting pomefruit tree production.

Acknowledgments Funding was provided by COST Action 864 and by Spain MICINN (Project AGL2006-13564-c02-01/AGR and AGL2009-13255-c02-01). The research group is under accreditation by SGR 2009-0812, XaRTA and TECNIO net from Catalonia.

\section{References}

Abadias M, Usall J, Teixidó N, Viñas I (2003) Liquid formulation of the postharvest biocontrol agent Candida sake CPA-1 in isotonic solutions. Phytopathology 93:436-442

Agustí L, Bonaterra A, Moragrega C, Camps J, Montesinos E (2011) Biocontrol of root rot of strawberry caused by Phytophthora cactorum with a combination of two Pseudomonas fluorescens strains. J Plant Pathol 93:363-372

Aumeran C, Paillard C, Robin F, Kanold J, Baud O, Bonnet R, Souweine B, Traore O (2007) Pseudomonas aeruginosa and Pseudomonas putida outbreak associated with contaminated water outlets in an oncohaematology paediatric unit. J Hosp Infect 65:47-53

Bashan Y, Hernandez JP, Leyva LA, Bacilio M (2002) Alginate microbeads as inoculant carriers for plant growth-promoting bacteria. Biol Fertil Soils 35:359-368

Batta YA (2004) Effect of treatment with Trichoderma harzianum Rifai formulated in invert emulsion on postharvest decay of apple blue mold. Int J Food Microbiol 96:281-288

Blum LEB, Amarante CVT, Valdebenito-Sanhueza RM, Guimaraes LS, Dezanet A, Hack-Neto P (2004) Postharvest application of Cryptococcus laurentii reduces apple fruit rots. Fitopatologia Brasileira 29:433-436

Bonaterra A, Camps J, Montesinos E (2005) Osmotically induced trehalose and glycine betaine accumulation improves tolerance to desiccation, survival and efficacy of the postharvest biocontrol agent Pantoea agglomerans EPS125. FEMS Microbiol Lett 250:1-8

Bonaterra A, Cabrefiga J, Camps J, Montesinos E (2007) Increasing survival and efficacy of a biocontrol agent of fire blight of rosaceous plants by means of osmoadaptation. FEMS Microbiol Ecol 61:185-195

Broggini GAL, Duffy B, Holliger E, Scharer HJ, Gessler C, Patocchi A (2005) Detection of the fire blight biocontrol agent Bacillus subtilis BD170 $\left(\right.$ Biopro $^{\circledR}$ ) in a Swiss apple orchard. Eur J Plant Pathol 111:93-100

Burgues HD, Jones KA (1998) Trends in formulation of microorganisms and future research requirements. In: Burgues HD (ed) Formulation of microbial pesticides. Beneficial microorganisms, nematodes and seed treatments. Kluwer, London, pp 311-331

Cabrefiga J, Bonaterra A, Montesinos E (2007) Mechanisms of antagonism of Pseudomonas fluorescens EPS62e against Erwinia amylovora, the causal agent of fire blight. Int Microbiol 10:123-132

Cabrefiga J, Francés J, Montesinos E, Bonaterra A (2011) Nutritional enhancement combined with osmoadaptation improve fitness and efficacy of a fire blight biocontrol agent. Appl Environ Microbiol 77:3174-3181

Calvo J, Calvente V, Orellano M, Benuzzi D, Sanz-de-Tosetti MI (2003) Improvement in the biocontrol of postharvest diseases of apples with the use of yeast mixtures. BioControl 48:579-593

Calvo J, Calvente V, de Orellano ME, Benuzzi D, de Tosetti MIS (2007) Biological control of postharvest spoilage caused by 
Penicillium expansum and Botrytis cinerea in apple by using the bacterium Rahnella aquatilis. Int J Food Microbiol 113:251-257

Castoria R, de Curtis F, Lima G, Caputo L, Pacifico S, de Cicco V (2001) Aureobasidium pullulans (LS-30), an antagonist of postharvest pathogens of fruits: study on its modes of action. Postharvest Biol Technol 22:7-17

Chand-Goyal T, Spotts RA (1996) Control of postharvest pear diseases using natural saprophytic yeast colonists and their combination with low dosage of thiabendazole. Postharvest Biol Technol 7:51-64

Chand-Goyal T, Spotts RA (1997) Biological control of postharvest diseases of apple and pear under semi-commercial and commercial conditions using three saprophytic yeasts. Biol Control 10:199-206

Compton J (1991) Nucleic acid sequence-based amplification. Nature 350:91-92

Cook RJ, Baker KF (1983) The nature and practice of biological control of plant pathogens. APS press, St Paul

Csonka LN, Hanson AD (1991) Prokaryotic osmoregulation: genetics and physiology. Annu Rev Microbiol 45:569-606

De Clercq D, Cognet S, Pujol M, Lepoivre P, Jijakli MH (2003) Development of a SCAR marker and a semi-selective medium for specific quantification of Pichia anomala strain K on apple fruit surfaces. Postharvest Biol Technol 29:237-247

Druvefors UA, Passoth A, Schnürer J (2005) Nutrient effects on biocontrol of Penicillium roqueforti by Pichia anomala J121 during airtight storage of wheat. Appl Environ Microbiol $71: 1865-1869$

EFSA (2007) Opinion of the Scientific Committee on a request from EFSA on the introduction of a Qualified Presumption of Safety (QPS) approach for assessment of selected microorganisms referred to EFSA. EFSA J 587:1-16

El Ghaouth A, Smilanick JL, Wisniewski M, Wilson CL (2000) Improved control of apple and citrus fruit decay with a combination of Candida saitoana and 2-deoxy-D-glucose. Plant Dis 84:249-253

Elkins RB, Rizzo DM, Whiting EC (1998) Biology and management of Armillaria root disease in pear in California. Acta Hort 475:453-458

El-Neshawy SM, Wilson CL (1997) Nisin enhancement of biocontrol of postharvest diseases of apple with Candida oleophila. Postharvest Biol Technol 10:9-14

European Commission (2000) Directive 2000/54/EC on the protection of workers from risks related to exposure to biological agents at work. Off J Eur Commun 262:21-45

Fan Q, Tian SP (2001) Postharvest biological control of grey mold and blue mold on apple by Cryptococcus albidus (Saito) Skinner. Postharvest Biol Technol 21:341-350

Filonow AB, Vishniac HS, Anderson JA, Janisiewicz WJ (1996) Biological control of Botrytis cinerea in apple by yeasts from various habitats and their putative mechanisms of antagonism. Biol Control 7:212-220

Flores A, Chet I, Herrera-Estrella A (1997) Improved biocontrol activity of Trichoderma harzianum by over-expression of the proteinase-encoding gene prb1. Curr Genet 31:30-37

Francés J, Bonaterra A, Moreno MC, Cabrefiga J, Badosa E, Montesinos E (2006) Pathogen aggressiveness and postharvest biocontrol efficiency in Pantoea agglomerans. Postharvest Biol Technol 39:299-307

Fravel DR, Rhodes DJ, Larkin RP (1999) Production and commercialization of biocontrol products. In: Albajes R, Gullino LM, van Lenteren JC, Elad Y (eds) Integrated pest and disease management in greenhouse crops. Kluwer, Dordrecht, pp 365-376

Ghabrial SA, Suzuki N (2009) Viruses of plant pathogenic fungi. Annu Rev Phytopathol 47:353-384
Girlanda M, Perotto S, Moenne-Loccoz Y, Bergero R, Lazzari A, Defago G, Bonfante P, Luppi AM (2001) Impact of biocontrol Pseudomonas fluorescens CHA0 and a genetically modified derivate on the diversity of culturable fungi in the cucumber rhizosphere. Appl Environ Microbiol 67:1851-1864

Gostincar C, Grube M, Gunde-Cimerman N (2011) Evolution of fungal pathogens in domestic environments? Fungal Biol. doi: 10.1016/j.funbio.2011.03.004

Guetsky R, Elad Y, Shtienberg D, Dinoor A (2002) Improved biocontrol of Botrytis cinerea on detached strawberry leaves by adding nutritional supplements to a mixture of Pichia guilermondii and Bacillus mycoides. Biocontrol Sci Technol 12:625630

Gullino ML, Kuijpers LAM (1994) Social and political implications of managing plant diseases with restricted fungicides in Europe. Annu Rev Phytopathol 32:559-579

Haas D, Défago G (2005) Biological control of soil-borne pathogens by fluorescent pseudomonads. Nat Rev Microbiol 3:307-319

Harman GE (2000) Myths and dogms of biocontrol. Plant Dis 84:377-393

Harman GE (2006) Overview of mechanisms and uses of Trichoderma spp. Phytopathology 96:190-194

Hase C, Moënne-Loccoz Y, Défago G (2001) Survival and cell culturability of biocontrol Pseudomonas fluorescens CHA0 in lysimeter effluent water and utilization of a deleterious genetic modification to study the impact of the strain on numbers of resident culturable bacteria. FEMS Microbiol Ecol 37:239-249

Ippolito A, El-Ghaouth A, Wilson CL, Wisniewski MA (2000) Control of postharvest decay of apple fruit by Aureobasidium pullulans and induction of defense responses. Postharvest Biol Technol 19:265-272

Ishimaru CA, Klos EJ, Brubaker RR (1988) Multiple antibiotic production by Erwinia herbicola. Phytopathology 78:746-750

Jamalizadeh M, Etebarian HR, Alizadeh A, Aminian H (2008) Biological control of gray mold on apple fruits by Bacillus licheniformis (EN74-1). Phytoparasitica 36:23-29

Janisiewicz WJ (1987) Postharvest biological control of blue mold on apples. Phytopathology 77:481-485

Janisiewicz WJ (1988) Biocontrol of postharvest diseases of apples with antagonist mixtures. Phytopathology 78:194-198

Janisiewicz WJ, Roitman J (1988) Biological control of blue mold and gray mold on apple and pear with Pseudomonas cepacia. Phytopathology 78:1697-1700

Janisiewicz WJ, Usall J, Bors B (1992) Nutritional enhancement of biocontrol of blue mold on apples. Phytopathology 82:1364-1370

Johnson KB, Stockwell VO, Sawyer TL, Sugar D (2000) Assessment of environmental factors influencing growth and spread of Pantoea agglomerans on and among blossoms of pear and apple. Phytopathology 90:1285-1294

Jones JB, Jackson LE, Balogh B, Obradovic A, Iriarte FB, Momol MT (2007) Bacteriophages for plant disease control. Annu Rev Phytopathol 45:245-262

Kanematsu S, Arakawa M, Oikawa Y, Onoue M, Osaki H, Nakamura H, Ikeda K, Kuga-Uetake Y, Nitta H, Sasaki A, Suzaki K, Yoshida K, Matsumoto N (2004) A reovirus causes hypovirulence of Rosellinia necatrix. Phytopathology 94:561-568

Kucheryava N, Fiss R, Auling G, Kroppenstedt RM (1999) Isolation and characterization of epiphytic bacteria from the phyllosphere of apple, antagonistic in vitro to Venturia inaequalis, the causal agent of apple scab. Syst Appl Microbiol 22:472-478

Larena I, Melgarejo P, Cal AD (2003) Drying of conidia of Penicillium oxalicum, a biological control agent against Fusarium Wilt of Tomato. J Phytopathol 151:600-606

Leben C (1965) Epiphytic microorganisms in relation to plant disease. Annu Rev Phytopathol 3:209-230 
Liu YZ, Chang YH, Wei BQ, Liu YF, Chen ZY (2009) Screening and evaluation of antagonistic bacteria against Botryosphaeria berengeriana f. sp. piricola. Chin J Fruit Sci 3:344-348

Lugtenberg B, Leveau J (2007) Biocontrol of plant pathogens: principles, promises, and pitfalls. In: Pinton R, Varanini Z, Nannipieri $P$ (eds) The rhizosphere: biochemistry and organic substances at the soil-plant interface, 2nd edn. CRC Press, Boca Raton, pp 267-296

Mari M, Guizzardi M, Pratella GC (1996) Biological control of gray mold in pears by antagonistic bacteria. Biol Control 7:30-37

Massart S, De Clercq D, Salmon M, Dickburt C, Jijakli MH (2005) Development of real-time PCR using minor groover binding probe to monitor the biological control agent Candida oleophila (strain O). J Microbiol Methods 60:73-82

Mathre DE, Cook RJ, Callan NW (1999) From discovery to use. Traversing the world of commercializing biocontrol agents for plant disease control. Plant Dis 83:972-983

McLaughlin RJ, Wilson CL, Chalutz E, Kurtzman WF, Osman SF (1990) Characterization and reclassification of yeasts used for biological control of postharvest diseases of fruit and vegetables. Appl Environ Microbiol 56:3583-3586

McLaughlin RJ, Wilson CL, Droby S, Ben-Arie R, Chalutz E (1992) Biological control of postharvest diseases of grape, peach and apple with the yeasts Kloeckera apiculata and Candida guilliermondii. Plant Dis 76:470-473

Mercier J, Wilson CL (1994) Colonization of apple wounds by naturally occurring microflora and introduced Candida oleophila and their effect on infection by Botrytis cinerea during storage. Biol Control 4:138-144

Mikani A, Etebarian HR, Sholberg PL, Gorman DT, Stokes S, Alizadeh A (2008) Biological control of apple gray mold caused by Botrytis mali with Pseudomonas fluorescens strains. Postharvest Biol Technol 48:107-112

Miller KJ, Wood JM (1996) Osmoadaptation by rhizosphere bacteria. Annu Rev Microbiol 50:101-136

Moënne-Loccoz Y, Naughton M, Higgins P, Powell J, O'Connor B, O'Gara F (1999) Effect of inoculum preparation and formulation on survival and biocontrol efficacy of Pseudomonas fluorescens F113. J Appl Microbiol 86:108-116

Molina L, Constantinescu F, Michel L, Reimmann C, Duffy B, Defago G (2003) Degradation of pathogen quorum-sensing molecules by soil bacteria: a preventive and curative biological control mechanism. FEMS Microbiol Ecol 45:71-81

Montesinos E (2003) Development, registration and commercialization of microbial pesticides for plant protection. Int Microbiol 6:245-252

Montesinos E, Bonaterra A (1996) Dose-response models in biological control of plant pathogens. An empirical verification. Phytopathology 86:464-472

Montesinos E, Bonaterra A (2009) Microbial pesticides. In: Schaechter M (ed) Encyclopedia of microbiology, 3rd edn. Elsevier, New York, pp 110-120

Nuclo RL, Johnson KB, Stockwell VO, Sugar D (1998) Secondary colonization of pear blossoms by two bacterial antagonists of the fire blight pathogen. Plant Dis 82:661-668

Nunes C, Teixido N, Usall J, Viñas I (2001) Biological control of major postharvest diseases on pear fruit with antagonistic bacterium Pantoea agglomerans (CPA-2). Acta Hort 553:403-404

Nunes C, Usall J, Teixido N, Fons E, Viñas I (2002) Postharvest biological control by Pantoea agglomerans (CPA-2) on Golden Delicious apples. J Appl Microbiol 92:247-255

Ongena M, Jacques P, Toure Y, Destain J, Jabrane A, Thonart P (2005) Involvement of fengycin-type lipopeptides in the multifaceted biocontrol potential of Bacillus subtilis. Appl Microbiol Biotechnol 69:29-38
Parke JL, Gurian-Sherman D (2001) Diversity of the Burkholderia cepacia complex and implications for risk assessment of biological control strains. Annu Rev Phytopathol 39:225-258

Plimmer JR (1999) Analysis, monitoring, and some regulatory implications. In: Hall FR, Menn JJ (eds) Methods in biotechnology, vol 5. Biopesticides: use and delivery. Humana Press, Totowa, pp 529-552

Powell KA, Jutsum AR (1993) Technical and commercial aspects of biocontrol products. Pest Sci 37:315-321

Pujol M, Badosa E, Manceau C, Montesinos E (2006) Assessment of the environmental fate of the biological control agent of fire blight, Pseudomonas fluorescens EPS62e, on apple by culturable and real-time PCR methods. Appl Environ Microbiol 72:2421-2427

Pujol M, Badosa E, Montesinos E (2007) Epiphytic fitness of a biological control agent of fire blight in apple and pear orchards under Mediterranean weather conditions. FEMS Microbiol Ecol 59:186-193

Ragsdale NN, Sisler HD (1994) Social and political implications of managing plant diseases with decreased availability of fungicides in the United States. Annu Rev Phytopathol 32:545-557

Rezzonico F, Smiths THM, Montesinos E, Frey JE, Duffy B (2009) Genotypic comparison of Pantoea agglomerans - plant and clinical strains. BMC Microbiol 9:204-209

Rhodes DJ (1993) Formulation of biological control agents. In: Jones DG (ed) Exploitation of microorganisms. Chapman and Hall, London, pp 411-439

Roberts RG (1990) Biological control of mucor rot of pear by Cryptococcus laurentii, C. flavus, and C. albidus. Phytopathology 80:1051-1154

Ryan PR, Dessaux Y, Thomashow LS, Weller DM (2009) Rhizosphere engineering and management for sustainable agriculture. Plant Soil 321:363-383

Ryder MH (1995) Monitoring of biocontrol agents and genetically engineered microorganisms in the environment: Biotechnological approaches. In: Rudra PS, Uma SS (eds) Molecular methods in plant pathology. CRC Press, Boca Raton, pp 475-492

Schaad NW, Cheong SS, Tamaki S, Hatziloukas E, Panopoulos NJ (1995) A combined biological and enzymatic amplification (BIO-PCR) technique to detect Pseudomonas syringae pv. phaseolicola in bean seed extracts. Phytopathology 85:243248

Schena L, Nigro F, Ippolito A, Gallitelli D (2004) Real-time quantitative PCR: a new technology to detect and study phytopathogenic and antagonistic fungi. Eur J Plant Pathol 110:893-908

Schisler DA, Slininger PJ, Behle RW, Jackson MA (2004) Formulation of Bacillus spp. for biological control of plant diseases. Phytopathology 94:1267-1271

Sharma RR, Singh D, Singh R (2009) Biological control of postharvest diseases of fruits and vegetables by microbial antagonists: a review. Biol Control 50:205-221

Smith VL, Wilcox WF, Harman GE (1990) Potential for biological control of Phytophthora root crown rots of apple by Trichoderma and Gliocladium spp. Phytopathology 80:880-885

Smits THM, Rezzonico F, Kamber T, Goesmann A, Ishimaru CA (2010) Genome sequence of the biocontrol agent Pantoea vagans Strain C9-1. J Bacteriol 192:6486-6487

Spadaro D, Garibaldi A, Gullino ML (2004) Control of Penicillium expansum and Botrytis cinerea on apple combining a biocontrol agent with hot water dipping and acibenzolar-S-methyl, baking soda, or ethanol application. Postharvest Biol Technol 33:141-151

Spadaro D, Gullino ML (2004) State of the art and future prospects of the biological control of postharvest fruit diseases. Int J Food Microbiol 91:185-194 
Spadaro D, Gullino ML (2005) Improving the efficacy of biocontrol agents against soilborne pathogens. Crop Prot 24:601-613

Spadaro D, Vola R, Piano S, Gullino ML (2002) Mechanisms of action and efficacy of four isolates of the yeast Metschnikowia pulcherrima active against postharvest pathogens on apples. Postharvest Biol Technol 24:123-134

Steinhäuser KG (2001) Environmental risks of chemicals and genetically modified organisms: a comparison. Part I: classification and characterization of risks posed by chemicals and GMOs. Environ Sci Pollut Res Int 8:120-126

Stockwell VO, Johnson KB, Sugar D, Loper JE (2011) Mechanistically compatible mixtures of bacterial antagonists improve biological control of fire blight of pear. Phytopathology 101:113-123

Sundin GW, Werner NA, Yoder KS, Aldwinckle HS (2009) Field evaluation of biological control of fire blight in the eastern United States. Plant Dis 93:386-394

Teixidó N, Viñas I, Usall J, Magan N (1998) Improving ecological fitness and environmental stress tolerance of the biocontrol yeast Candida sake by manipulation of intracellular sugar alcohol and sugar content. Mycol Res 102:1409-1417

Temple TN, Johnson KB (2011) Evaluation of loop-mediated isothermal amplification for rapid detection of Erwinia amylovora on pear and apple fruit flowers. Plant Dis 95:423-430

Tomita N, Mori Y, Kanda H, Notomi T (2008) Loop-mediated isothermal amplification (LAMP) of gene sequences and simple visual detection of products. Nat Protoc 3:877-882

Utkhede RS, Sholberg PL, Smirle MJ (2001) Effects of chemical and biological treatments on growth and yield of apple trees planted in Phytophthora cactorum infested soils. Can J Plant Pathol 23:163-167

Utkhede RS, Smith EM (1997) Effectiveness of dry formulations of Enterobacter agglomerans for control of crown and root rot of apple trees. Can J Plant Pathol 19:397-401

van Elsas JD, Duarte GF, Rosado AS, Smalla K (1998) Microbiological and molecular biological methods for monitoring microbial inoculants and their effects in the soil environment. J Microbiol Method 32:133-154

van Elsas JD, Migheli Q (1999) Evaluation of risks related to the release of biocontrol agents active against plant pathogens. In: Albajes $\mathrm{R}$ et al (eds) Integrated pest and disease management in greenhouse crops. Kluwer, The Netherlands, pp 377-393

van Veen JA, van Overbeek LS, van Elsas JD (1997) Fate and activity of microorganisms introduced into soil. Microbiol Mol Biol Rev $61: 121-135$
Vicedo B, Peñalver R, Asins MJ, López MM (1993) Biological control of Agrobacterium tumefaciens, colonization, and pAgK84 transfer with $A$. radiobacter $\mathrm{K} 84$ and the tra- mutant strain K1026. Appl Environ Microbiol 59:309-315

Viñas I, Usall J, Teixido N, Fons E, Ochoa-de-Eribe J (1996) Successful biological control of the major postharvest diseases on apple and pear with a new strain of Candida sake. In: Proceedings of the British crop protection conference on pests and diseases 6C, pp 603-608

Viñas I, Usall J, Teixido N, Sanchis V (1998) Biological control of major postharvest pathogens on apple with Candida sake. Int $\mathbf{J}$ Food Microbiol 40:9-16

Walsh UF, Morrissey JP, O'Gara F (2001) Pseudomonas for biocontrol of phytopathogens: from functional genomics to commercial exploitation. Current Opin Biotechnol 12:289-295

Welsh DT, Herbert RA (1999) Osmotically induced intracellular trehalose, but not glycine betaine accumulation promotes desiccation tolerance in Escherichia coli. FEMS Microbiol Lett 174:57-63

Wilson M, Epton HAS, Sigee DC (1992) Interactions between Erwinia herbicola and E. amylovora on the stigma of hawthorn blossoms. Phytopathology 82:914-918

Wilson M, Lindow SE (1993) Interactions between the biological control agent Pseudomonas fluorescens A506 and Erwinia amylovora in pear blossoms. Phytopathology 83:117-123

Wright SAI, Zumoff CH, Schneider L, Beer SV (2001) Pantoea agglomerans strain EH318 produces two antibiotics that inhibit Erwinia amylovora in vitro. Appl Environ Microbiol 67:284-292

Zhang H, Wang L, Ma L, Dong Y, Jiang S, Xu B, Zheng X (2009) Biocontrol of major postharvest pathogens on apple using Rhodotorula glutinis and its effects on postharvest quality parameters. Biol Control 48:79-83

Zhang H, Zheng X, Fu C, Xi Y (2003) Biocontrol of postharvest blue mould rot of pear by Cryptococcus laurentii. J Hort Sci Biotechnol 78:888-893

Zhang H, Zheng X, Fu C, Xi Y (2005) Postharvest biological control of gray mold rot of pear with Cryptococcus laurentii. Postharvest Biol Technol 35:79-86

Zhou T, Chu CL, Liu WT, Schneider KE (2001) Postharvest control of blue mold and gray mold on apples using isolates of Pseudomonas syringae. Can J Plant Pathol 23:246-252 